\title{
Pendugaan Umur Simpan Sirup Buah Semu Jambu Mete (Anacardium Occidentale, L) dengan Metode Accelerated Shelf Life Testing (ASLT)
}

\author{
Afriyanti $^{1)}$, Novian Wely Asmoro ${ }^{2)}$ \\ 1)2)Fakultas Pertanian, Jurusan Teknologi Hasil Pertanian, Universitas Veteran Bangun Nusantara, \\ Jl. Letjend S. Humardani No 1 Jombor Sukoharjo, Telp (0271) 593156, email: afriyantistp@gmail.com
}

\begin{abstract}
Abstrak
Sirup buah semu jambu mete merupakan salah satu alternatif pengolahan buah semu jambu mete yang selama ini masih belum dimanfaatkan secara optimal. Umur simpan dari sirup ini belum diketahui dengan jelas sehingga perlu adanya penelitian lebih lanjut. Tujuan penelitian ini adalah untuk mengetahui berapa lama umur simpan produk sirup buah semu jambu mete yang selama ini diproduksi oleh produsen sirup dengan metode Accelerated Shelf Life Testing (ASLT). Pembuatan sirup dalam penelitian ini mengikuti prosedur yang biasa dilakukan oleh masyarakat. Sirup dikemas dalam botol-botol dengan volume $150 \mathrm{ml}$ kemudian disimpan pada suhu $5^{\circ} \mathrm{C}, 27^{\circ} \mathrm{C}$, dan $50^{\circ} \mathrm{C}$. Analisis dilakukan setiap 7 hari sekali terhadap warna, $\mathrm{pH}$, dan total koloni. Hasil penelitian menunjukkan umur simpan sirup buah jambu mete berdasarkan parameter perubahan jumlah koloni mikrobia adalah 48 hari.
\end{abstract}

Kata kunci: $A S L T$, buah semu jambu mete, sirup, umur simpan

\begin{abstract}
Cashew fruit syrup is one of the alternative processing of cashew fruit that has been still not utilized optimally. The shelf life of this syrup is not known clearly, so there is a need for further research. The purpose of this study is to find out how long the shelf life of cashew fruits syrup that has been produced by syrup manufacturers with Accelerated Shelf Life Testing (ASLT) method. Syrup production in this study follows the usual procedures performed by the community. The syrup is packed in $150 \mathrm{ml}$ bottles and then stored at $5{ }^{\circ} \mathrm{C}, 27^{\circ} \mathrm{C}$, and $50^{\circ} \mathrm{C}$. Analysis is done every 7 days against color, $\mathrm{pH}$, and total colony. The result of this study showed that the shelf life of cashew nut fruits based on the parameters of change of microbial colony count was 48 days.
\end{abstract}

Keywords: ASLT, cashew fruit, shelf life, syrup

\section{PENDAHULUAN}

Indonesia memiliki areal perkebunan jambu mete (Anacardium occidentale L.) yang cukup luas. Salah satunya di daerah Jatisrono, Wonogiri, Jawa Tengah. Pemanfaatan buah semu jambu mete di Jatisrono, Wonogiri masih dalam jumlah terbatas. Hanya sekitar $20 \%$ yang dimanfaatkan, sedangkan sisanya hanya menjadi limbah. Buah ini memiliki kandungan karbohidrat yang cukup tinggi sekitar 15,3 $\mathrm{g} / 100 \mathrm{~g}$ buah. Kandungan vitamin $\mathrm{C}$ juga sangat tinggi yaitu $197 \mathrm{mg} / 100 \mathrm{~g}$ buah (Sutanto, 2012).
Jambu mete memiliki rasa sepat karena kandungan tannin yang cukup tinggi. Tanin dapat berkurang melalui beberapa perlakuan baik secara fisik, kimia maupun keduanya. Jambu mete yang sepat dan kurang diminati warga dapat diolah menjadi suatu produk makanan yang dapat disukai sehingga dapat meningkatkan nilai jual jambu mete yang kaya akan vitamin C tersebut. Salah satunya dengan diolah menjadi sirup buah jambu mete.

Sirup buah semu jambu mete merupakan produk yang tidak tahan lama, 
Agrisaintifika

Jurnal Ilmu-Ilmu Pertanian

Vol. 1, No. 2, 2017

tetapi belum diketahui dengan jelas umur simpannya. Beberapa produk sirup sejenis memiliki umur simpan yang relatif pendek seperti sirup temulawak dengan umur simpan 45 hari (Suwita dkk, 2012), sirup buah pala selama 34 hari (Aryani, 2013), sari wortel nanas selama 25 hari (Pratiwi, 2009) dan sari akar alang-alang selama 41 hari (Anagari dkk, 2011). Selama ini sudah terdapat banyak penelitian pembuatan sirup buah semu jambu mete (Widyasari, 2007), tetapi informasi mengenai umur simpannya belum diketahui.

Keterangan umur simpan (masa kadaluarsa) produk pangan merupakan salah satu informasi yang wajib dicantumkan oleh produsen pada label kemasan produk pangan, terkait dengan keamanan produk pangan dan untuk memberikan jaminan mutu pada saat produk sampai ke tangan konsumen. Kewajiban pencantuman masa kadaluarsa pada label pangan diatur dalam Undang-undang Pangan no.7/1996 serta Peraturan Pemerintah No. 69/1999 tentang Label dan Iklan Pangan, setiap industri pangan wajib mencantumkan tanggal kadaluarsa (expired date) pada setiap kemasan produk pangan. Umur simpan sirup buah jambu mete belum diteliti sebelumnya.

Penelitian umur simpan sirup buah semu jambu mete ini menggunakan metode Accelerated Shelf Life Testing (ASLT). Metode ini menggunakan kondisi suatu kondisi lingkungan yang dapat mempercepat terjadinya reaksi-reaksi penurunan mutu produk pangan (Labuza, 1982). Waktu pengujian yang dilakukan relatif singkat tetapi keakuratan dan akurasinya tinggi. Selanjutnya digunakan pendekatan Arrhenius sebagai persamaan untuk memperhitungkan perubahan energi aktivasi. Hasil akhir akan diperoleh umur simpan pada suhu ruang yaitu $27^{\circ} \mathrm{C}$.

Manfaat yang diharapkan dari penelitian ini adalah didapatkannya informasi mengenai umur simpan produk sirup buah semu jambu mete sehingga dapat digunakan sebagai acuan oleh unit-unit usaha atau UKM produsen sirup buah semu jambu mete.
Bahan baku yang digunakan dalam pembuatan sirup buah semu jambu mete adalah buah semu jambu mete (Anacardium occidentale, L) varietas merah yang diperoleh dari daerah Sumberjo, Kecamatan Jatisrono, Kabupaten Wonogiri.

\subsection{Metode}

Proses pembuatan sirup buah semu jambu mete dalam penelitian ini mengikuti prosedur yang telah biasa dilakukan oleh masyarakat atau produsen sirup selama ini. Untuk bahan sirup digunakan buah semu yang baru dipanen yang sebelumnya sudah dikukus atau direndam dalam larutan garam 2,5\% selama 4 jam. Setelah dicuci buah dipotong-potong kemudian diblender atau dipress sehingga diperoleh bubur. Bubur tersebut disaring dengan menggunakan kain saring/saringan plastik sehingga diperoleh sari (filtrat). Selanjutnya ke dalam filtrat tersebut tambahkan gula dengan perbandingan 1:1 kemudian diaduk sampai gula larut. Setelah gula larut disaring kembali dengan tujuan supaya filtrat bebas dari kotoran yang berasal dari gula. Selanjutnya filtrat siap untuk dimasak sampai mendidih sebelum diangkat tambahkan asam sitrat $0,2 \%$. lalu diangkat dan siap untuk dikemas dalam keadaan panas langsung ditutup dan segera dipasteurisasi.

Pengemasan dilakukan dalam botolbotol dengan volume $150 \mathrm{ml}$. Sirup yang sudah siap kemas dibagi dalam 30 botol untuk persiapan analisis. Sebanyak 10 botol disimpan dalam suhu $5^{\circ} \mathrm{C}, 10$ botol disimpan dalam suhu $27^{\circ} \mathrm{C}$ dan 10 botol disimpan dalam suhu $50^{\circ} \mathrm{C}$. Sebelum penyimpanan dilakukan pengukuran $\mathrm{pH}$, uji warna, uji mikrobiologi dengan plating. Hasilnya digunakan sebagai kontrol. Setiap 7 hari sekali dilakukan sampling untuk dilakukakan analisis seperti pada kontrol.

\section{BAHAN DAN METODE}

\subsection{Bahan}

\section{HASIL DAN PEMBAHASAN}

\subsection{Analisis Warna}


Parameter pertama dari sebuah produk yang terlihat oleh konsumen adalah warna sehingga parameter ini dapat menjadi salah satu acuan yang digunakan konsumen dalam menilai mutu suatu produk pangan. Pada beberapa jenis produk, perubahan warna dapat menunjukkan perubahan nilai gizi, sehingga perubahan warna dapat dijadikan sebagai indikator untuk menunjukkan tingkat nilai gizi maksimum yang dapat diterima (Arpah, 2001). Oleh karena itu, perubahan warna dapat digunakan sebagai parameter untuk memperkirakan lama penyimpanan produk.

Warna sirup buah jambu mete diukur dengan menggunakan Chromameter. Parameter warna yang digunakan adalah $\mathrm{L}$ (kecerahan), a (warna kromatik campuran merah-hijau), b (warna kromatik campuran biru-kuning). Hasil pengukuran warna sirup buah jambu mete menunjukkan bahwa perbedaan suhu penyimpanan mempengaruhi perubahan warna sirup. Semakin tinggi suhu penyimpanan, tingkat kecerahan semakin rendah. Selain itu, waktu penyimpanan sirup juga berpengaruh terhadap perubahan warna sirup. Semakin lama waktu penyimpanan, warna sirup semakin gelap yang ditandai dengan nilai $L$ yang semakin menurun. Hal ini dapat dilihat pada Gambar 1, Gambar 2 dan Gambar 3 (Lampiran 1).

Interaksi antara suhu dan lama penyimpanan ternyata memberikan pengaruh yang signifikan terhadap perubahan warna sirup. Semakin tinggi suhu dan semakin lama waktu penyimpanan menyebabkan kecerahan warna sirup semakin menurun. Hal ini dapat dilihat dari gambar yang menunjukkan warna sirup semakin pekat. Perubahan warna yang terlihat sangat signifikan terjadi pada sirup buah jambu mete yang disimpan pada suhu $50^{\circ} \mathrm{C}$. Menurut Muchtadi (2010), penyebab dari perubahan warna disebabkan oleh reaksi kimia gula dan asam amino dari protein yang dikenal sebagai reaksi pencoklatan (browning) atau reaksi Maillard. Reaksi Maillard terjadi bila bahan pangan mengalami pemanasan atau penyimpanan. Beberapa reaksi Maillard dapat menyebabkan warna kehitaman atau bau tidak sedap pada makanan tidak diharapkan (Afrianto et al. 2008).

Hasil analisis warna pada tiga suhu yang berbeda (Lampiran 2) menghasilkan persamaan garis linier sebagai berikut:

$$
y=-3875.3 x+11.844
$$

Dengan kata lain, grafik merupakan

persamaan hubungan In $\mathrm{k}$ versus $1 / \mathrm{T}$ yaitu:

$$
\text { In } \mathrm{k}=-3875.3(1 / \mathrm{T})+11.844
$$

Persamaan tersebut kemudian digunakan untuk menghitung nilai $\mathrm{k}$ pada proyeksi suhu penyimpanan sirup buah jambu mete. Pada produk ini, produk disimpan pada suhu $30^{\circ} \mathrm{C}$, maka dari persamaan diperoleh nilai In $\mathrm{k}=-1.074$ atau $\mathrm{k}=0.3416$ (terjadi penurunan tingkat kecerahan warna sirup sebesar 0,0224 per hari). Berdasarkan selisih nilai kecerahan awal sirup buah jambu mete (54.63) dengan nilai akhir saat penyimpanan (47.98), maka didapatkan umur simpan sirup buah jambu mete selama 19.5 hari.

\subsection{Analisis pH}

Rata - rata nilai $\mathrm{pH}$ sirup buah buah jambu mete yang diukur selama 28 hari dengan interval pengukuran setiap tujuh hari sekali dapat dilihat pada Gambar 8 .

Analisis statistik menunjukkan bahwa interaksii antara suhu dan lama penyimpanan memberikan pengaruh yang signifikan terhadap perubahan nilai $\mathrm{pH}$ sirup yang ditunjukkan oleh gambar di atas. Nilai $\mathrm{pH}$ semakin menurun seiring dengan kenaikan suhu dan lama penyimpanan (Lampiran 3). Hal ini kemungkinan disebabkan oleh aktivitas mikrobia selama penyimpanan sehingga $\mathrm{pH}$ menurun.

Hasil perhitungan $\mathrm{pH}$ pada ketiga suhu menghasilkan persamaan garis linier sebagai berikut:

$$
y=-693.37 x-1.5479
$$

Dengan kata lain, grafik merupakan persamaan hubungan In $\mathrm{k}$ versus $1 / \mathrm{T}$ yaitu:

$$
\text { In } k=-693.37(1 / T)-1.5479
$$

Persamaan tersebut kemudian digunakan untuk menghitung nilai $\mathrm{k}$ pada proyeksi suhu penyimpanan sirup buah jambu mete. Pada produk ini, produk disimpan pada suhu $30^{\circ} \mathrm{C}$, maka dari persamaan diperoleh nilai $\mathrm{In} \mathrm{k}=-3.8362$ atau $\mathrm{k}=0.0216$ (terjadi penurunan nilai $\mathrm{pH}$ sirup sebesar 
0,0216 per hari). Berdasarkan selisih nilai $\mathrm{pH}$ awal sirup buah jambu mete (4.1) dengan nilai akhir saat penyimpanan (3.6), maka didapatkan umur simpan sirup buah jambu mete selama 23 hari.

\subsection{Perhitungan Total Koloni Mikrobia}

Hasil penelitian menunjukkan bahwa semakin lama penyimpanan maka jumlah total mikroganisme sirup cenderung semakin meningkat (Lampiran 4)

Hasil perhitungan total koloni pada ketiga suhu menghasilkan persamaan garis linier ditunjukkan oleh persamaan di bawah ini:

$$
y=-1298.4 x+11.466
$$

Dengan kata lain, grafik merupakan persamaan hubungan In $\mathrm{k}$ versus $1 / \mathrm{T}$ yaitu:

In $\mathrm{k}=-1298.4(1 / \mathrm{T})+11.466$

Produk diproyeksikan disimpan pada suhu $30^{\circ} \mathrm{C}$, maka dari persamaan diperoleh nilai In $\mathrm{k}=7.138$ atau $\mathrm{k}=1258.908$ (terjadi peningkatan pertumbuhan mikroba sebesar 1258.908 per hari). Jumlah mikrobia di akhir penyimpanan adalah 60500 koloni/ml sehingga didapat umur simpan selama 48,06 hari.

Perhitungan total mikroorganisme menggunakan prinsip hitungan cawan yaitu dengan menggunakan PCA (Plate Count Agar) sebagai suatu medium pemupukan sehingga semua mikroba termasuk bakteri, kapang, dan khamir dapat tumbuh dengan baik pada medium tersebut (Fardiaz, 1993). Lampiran 4 menunjukkan rata - rata jumlah total mikroba pada sirup yang disimpan pada suhu $5^{\circ} \mathrm{C}$ lebih sedikit dibandingkan dengan sirup yang disimpan pada suhu tinggi disebabkan karena kebanyakan mikroorganisme tahan terhadap suhu rendah sampai suhu pembekuan dan walaupun pertumbuhan dan pembelahan mungkin terhambat, sel-sel bakteri dapat tahan hidup untuk jangka waktu cukup lama pada suhu pendinginan $\pm 5^{\circ} \mathrm{C}$ (Buckle, 1985).

Mikrobia merupakan salah satu parameter yang sensitif terhadap perubahan suhu. Oleh karena itu, pendugaan umur simpan sirup jambu mete ini didasarkan pada hasil perhitungan metode Arrhenius dengan parameter perubahan jumlah koloni mirobia yaitu selama 48 hari. Hasil perhitungan umur simpan sirup buah jambu mete ini ternyata tidak berbeda jauh dengan umur simpan beberapa produk sejenis.

\section{KESIMPULAN}

Umur simpan produk sirup buah jambu mete yang selama ini diproduksi oleh produsen sirup dengan menggunakan metode Accelerated Shelf Life Testing (ASLT) berdasarkan parameter perubahan jumlah koloni mirobia didapatkan umur simpan selama 48 hari.

\section{DAFTAR PUSTAKA}

Afrianto, E., dkk. 2008. Pengawasan Mutu Bahan / Produk Pangan. Departemen Pendidikan Nasional, Jakarta.

Anagari, Hesti dkk. 2011. Penentuan Umur Simpan Minuman Fungsional Sari Akar Alang-alang dengan Metode Accelerated Shelf Life Testing (ASLT) (Studi Kasus di UKM "R Rovit" Batu, Malang). Agrointek Vol 5 No 2 Agustus 2011.

Arpah. 2001. Buku dan Monograf Penentuan Kadaluarsa Produk. Program Studi IImu Pangan. Institut Pertanian Bogor. Bogor.

Aryani, Ghesi W. 2013. Pendugaan Umur Simpan dengan Metode Accelerated Shelf Life Testing (ASLT) pada Produk Bandrek Instan dan Sirup Buah Pala (Myristica fragrans, Houtt) di Desa Sinarsari dan Dramaga Kabupaten Bogor. Skripsi. Fakultas Teknologi Pertanian, Institut Pertanian Bogor. Bogor.

Buckle, K. A., Edwards, R. A., Fleet, G. H., dan Wootton, M. 1985. Ilmu Pangan. Terjemahan Hari Purnomo dan Adiono. UI Pers. Jakarta.

Fardiaz, S. 1992. Mikrobiologi Pangan. Gramedia Pustaka Utama, Jakarta.

Labuza, T.P and Riboh, D. 1982. Theory and Application of Arrhenius Kinetics to the 
Afriyanti \& Asmoro. 2017

Prediction of Nutrien Losses in Food. Food Technology 36: 66-74.

Muchtadi, T.R. 2010. Teknologi Proses Pengolahan Pangan. AlfaBeta, Bandung.

Pratiwi. 2009. Formulasi, Uji Kecukupan Panas dan Pendugaan Umur Simpan Minuman Sari Wornas (Wortel-Nanas). Skripsi. Fakultas Teknologi Pertanian, Institut Pertanian Bogor. Bogor.

Sutanto, Ratuca S. 2012. Pengaruh pH Substrat terhadap Kadar Serat, Vitamin C dan Tingkat Penerimaan Nata de Cashew (Anacardium occidentale L). Skripsi. Fakultas
Teknologi Pertanian, Institut Pertanian Bogor. Bogor.

Suwita, Komang dkk. 2012. Pendugaan Umur Simpan Sirup Temulawak (Curcuma xanthorrhiza Roxb), Madu dan Ekstrak Ikan Gabus (Ophiocephalus striatus) dengan Model Arrhenius dan Model $\mathrm{Q}_{10}$. Skripsi. Politeknik Kesehatan Kemenkes. Malang.

Widyasari, Rucitra. 2007. Aplikasi Penambahan Flokulan terhadap Pengolahan Sari Buah Jambu Mete (Anacardium occidentale, L). Skripsi. Fakultas Teknologi Pertanian, Institut Pertanian Bogor, Bogor. 
Agrisaintifika

Jurnal Ilmu-Ilmu Pertanian

Vol. 1, No. 2, 2017

Afriyanti \& Asmoro. 2017

Lampiran 1. Perubahan warna sirup

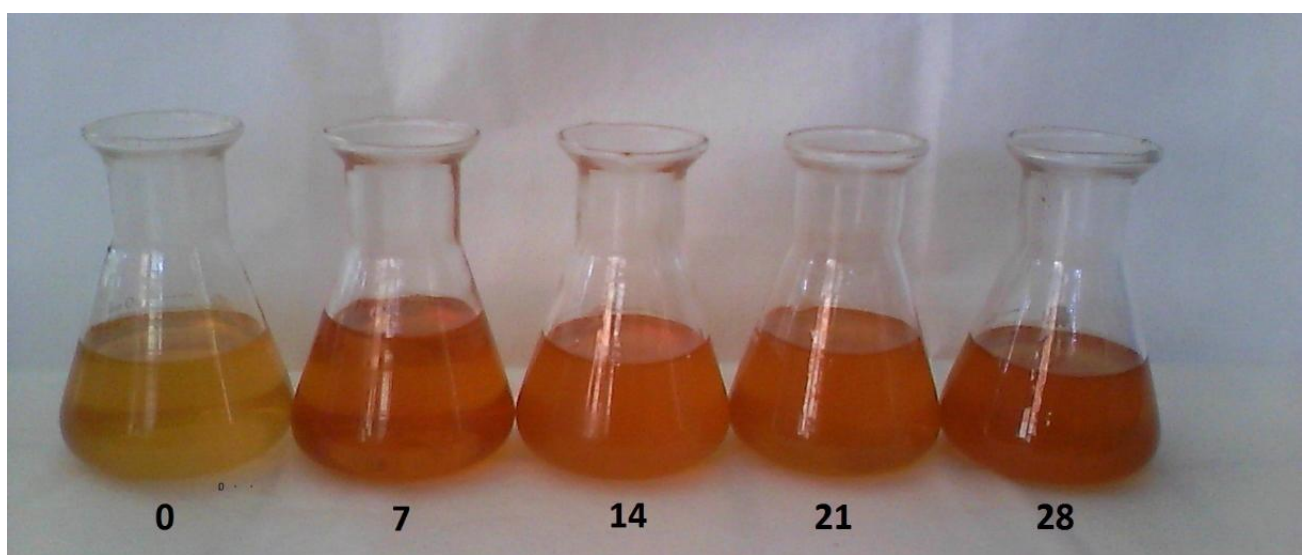

Gambar 1. Perubahan warna sirup buah jambu mete pada suhu $5^{\circ} \mathrm{C}$ selama 28 hari

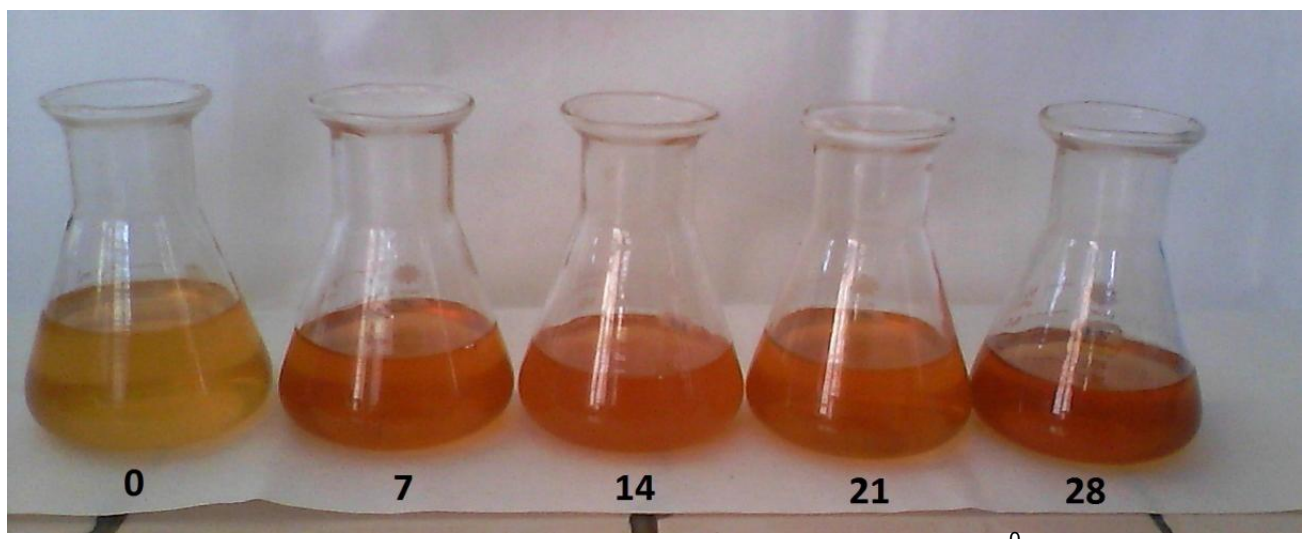

Gambar 2. Perubahan warna sirup buah jambu mete pada suhu $27^{\circ} \mathrm{C}$ selama 28 hari

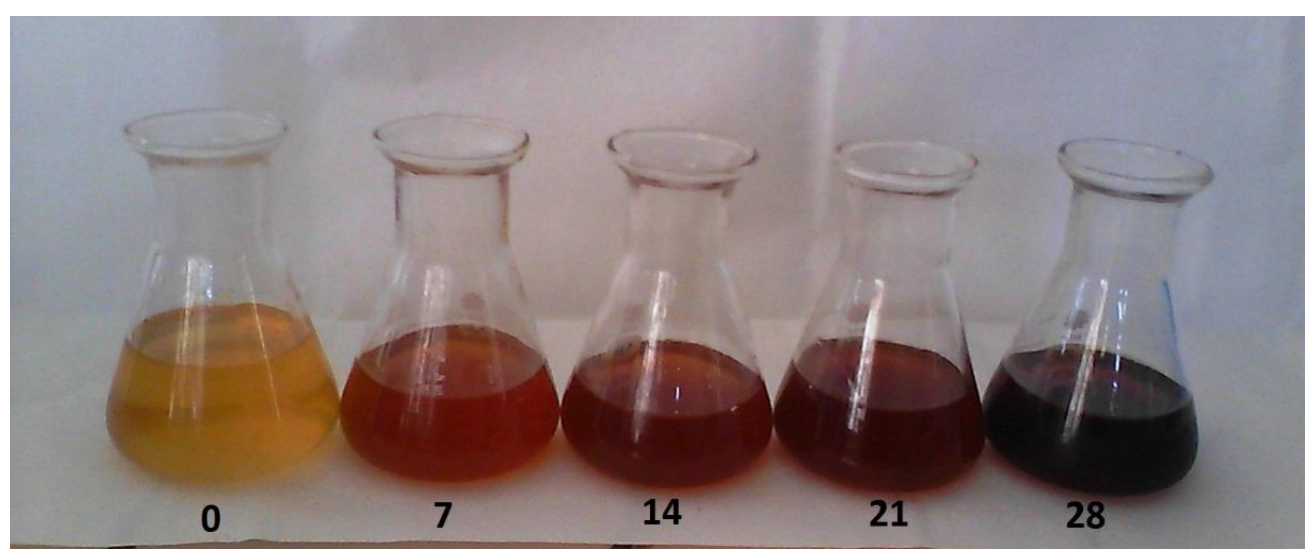

Gambar 3. Perubahan warna sirup buah jambu mete pada suhu $50^{\circ} \mathrm{C}$ selama 28 hari

Lampiran 2. Hasil analisis warna pada tiga suhu yang berbeda 
Agrisaintifika

Jurnal Ilmu-Ilmu Pertanian

Vol. 1, No. 2, 2017

Afriyanti \& Asmoro. 2017

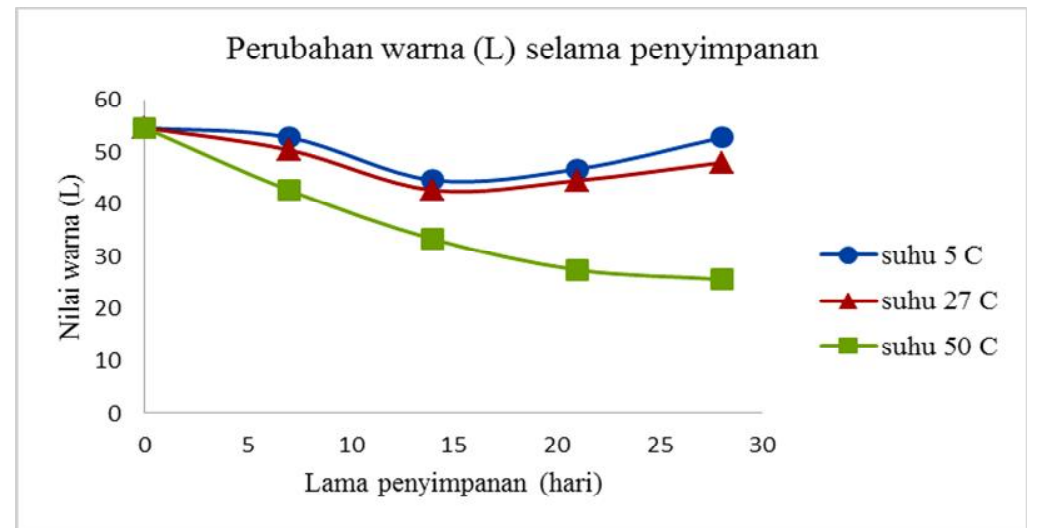

Lampiran 3. Hasil perhitungan $\mathrm{pH}$ pada tiga suhu yang berbeda

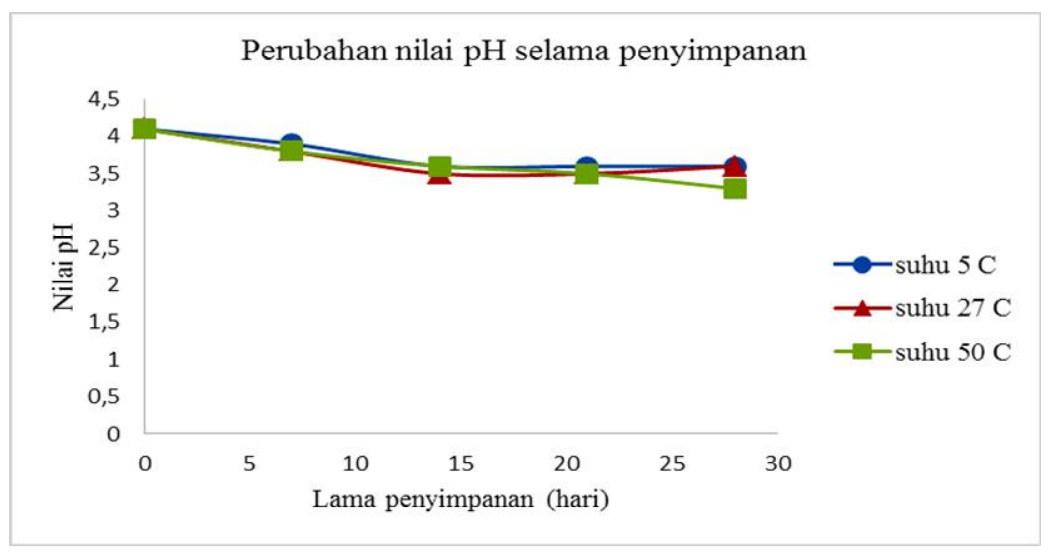

Lampiran 4. Hasil perhitungan total koloni mikrobia pada tiga suhu yang berbeda

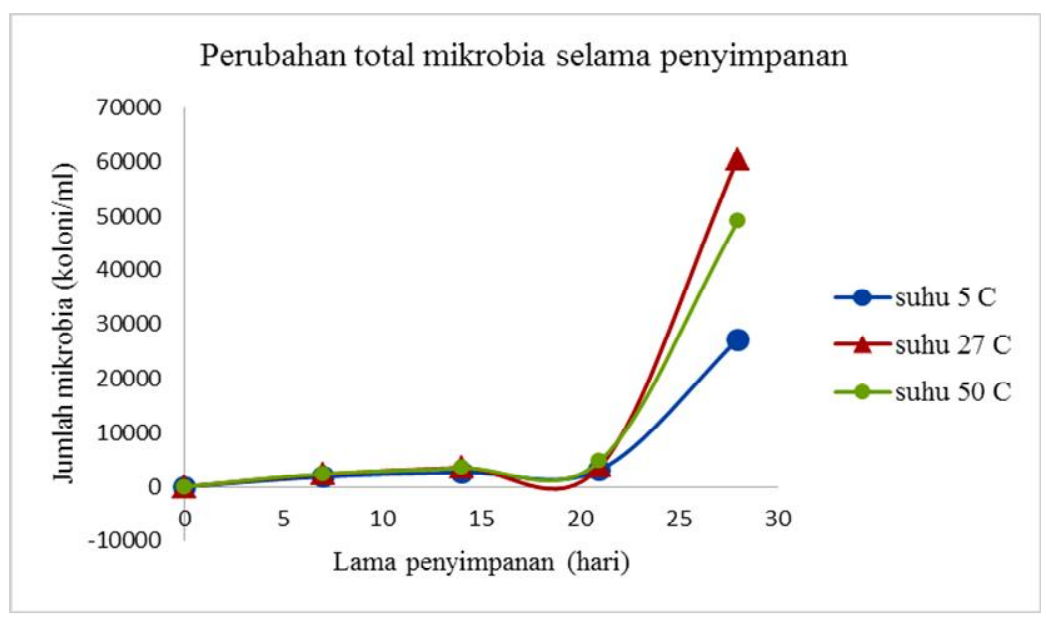

